\title{
PELATIHAN SECARA DARING MENGENAI PEMBUATAN PRODUK MINUMAN FERMENTASI DI SEKOLAH DIAN HARAPAN
}

\author{
Natania $^{1}$, Ratna Handayani ${ }^{2}$, Hardoko ${ }^{3}$ \\ ${ }^{1}$ Kepala Laboratorium Pengolahan Pangan, Jurusan Teknologi Pangan Universitas Pelita \\ Harapan \\ ${ }^{2}$ Jurusan Teknologi Pangan Universitas Pelita Harapan \\ ${ }^{3)}$ Jurusan Teknologi Hasil Perikanan, Fakultas Perikanan dan Ilmu Kelautan, Universitas \\ Brawijaya, Malang \\ natania.fti@uph.edu, ratna.handayani@uph.edu, hardoko.fti@uph.edu
}

\begin{abstract}
Abstrak
Siswa sekolah menengah atas merupakan generasi penerus bangsa. Masa-masa SMA biasanya siswa dihadapkan pada salah satu pilihan sulit, yaitu menentukan tujuan masa depan. Melalui pengabdian masyarakat ini diharapkan siswa-siswa akan diperkenalkan secara umum kepada bidang ilmu teknologi pengolahan makanan dan secara khusus kepada teknologi fermentasi. Fermentasi merupakan salah satu Teknik pengolahan pangan yang paling tua, dimana melalui fermentasi, makanan bukan saja diperpanjang umur simpannya tetapi juga dilakukan pengolahan dengan memanfaatkan mikroorganisme untuk meningkatkan gizi, rasa dan sifat fungsionalnya. Teknologi fermentasi saat inibukan hanya diaplikasikan pada produk makanan, tetapi teknologi fermentasi sekarang ini merupakan salah satu teknologi dasar yang digunakan untuk menghasilkan obat-obatan maupun sumber daya energi yang terbarukan. Teknologi fermentasi merupakan teknologi yang erat kaitannya denganpotensi pemberdayaan alam, baik sebagai sumber makanan maupun sebagai sumber energi. Banyak sekali produk-produk fermentasi yang beredar di masyarakat. Melalui pelatihan ini, siswa akan diperkenalkan kepada dasar- dasar teknologi fermentasi, jenisjenis produk fermentasi dan juga potensi/aplikasi dari teknologi fermentasi dalam kehidupan. Siswa juga akan diberi bimbingan dan kesempatan untuk mempraktekkan teknologi fermentasi secara sederhana di rumah. Diharapkan melalui pengabdian masyarakat ini, pengertian dan minat siswa-siswa untuk mempelajari teknologi terutama yang berhubungan dengan teknologi pangan meningkat.
\end{abstract}

Kata kunci : Pemberdayaan Siswa, Teknologi Fermentasi, Teknologi Pangan

\section{PENDAHULUAN}

Ketika Allah menciptakan manusia, salah satu mandat budaya yang diberikan adalah bagaimana manusia harus dapat menguasai dan mengusahakan alam semesta. Salah satu cara yang dapat dilakukan manusia untuk mengusahakan alam semesta adalah dengan mempelajari mengenai ilmu-ilmu alam. Walaupun begitu rendahnya minat manusia untuk mempelajari ilmu alam, banyak berhubungan dengan adanya kepercayaan bahwa bidang ilmu alam merupakan ilmu yang menakutkan dan tidak menghasilkan uang. Menurut sebuah penelitian di inggris, jumlah siswa yang menunjukkan ketertarikan pada bidang ilmu alam dan Teknik memiliki penurunan yang cukup pesat, sehingga ada kemungkinan adanya kekurangan peneliti di masa yang akan datang [1, 2]. Dari keseluruhan responden sebanyak 51\% siswa mengangap pelajaran sains adalahpelajaran yang sulit, 
membingungkan, dan membosankan dan $79 \%$ siswa berpendapat bahwa pelajaran sains merupakan pelajaran untuk orang pintar saja.

Siswa sekolah menengah atas pada khususnya, adalah generasi penerus yang akan melanjutkan pekerjaan generasi sebelumnya dalam memelihara alam semesta. Sekolah Dian Harapan menangkap pentingnya memberikan informasi sebanyak-sebanyaknya kepada siswa-siswa mereka mengenai aneka pilihan jurusan/ilmu yang bisa siswa-siswa tersebut pilih pada waktu kuliah. Pendidikan Sains sebenarnya bukan saja ilmu hafalan melainkan melalui Pendidikan sains, siswa-siwa dilatih untuk mengembangkan kemampuan dasar ilmiah seperti; mengamati, mencatat, menafsirkan, mengambil kesimpulan dan membuat rancangan. Hal-hal ini sebenarnya merupakan kemampuan dasar yang dibutuhkan oleh manusia untuk dapat berfungsi sebagaimana mestinyadalam kehidupan social [3].

Kegiatan pengabdian kepada masyarakat kali ini bertemakan pengenalan teknologi pangan dan teknologi fermentasi, dan dilakukan berdasarkan permintaan dari Sekolah Dian Harapan. Salah satu misi Jurusan Teknologi Pangan Universitas Pelita Harapan yaitu mewujudkan pembelajaran di bidang ilmu dan teknologi pangan yang sesuai dengan kebutuhan masyarakat. Melalui program kerjasama dengan Sekolah Dian Harapan, maka jurusan teknologi pangan diberikan waktu intensif selama dua minggu, untuk membantu memperkenalkan mengenai jurusan teknologi pangan pada umumnya dan teknologi fermentasi pada khususnya kepada siswa-siswa sekolah menengah atas di SDH.

Fermentasi merupakan salah satu Teknik pengolahan pangan yang paling tua, dimana melalui fermentasi, manusia bukan saja dapat mengawetkan makanan tetapi juga meningkatkan nilai rasa dan gizi dan umur simpan dari makanan [4]. Teknologi fermentasi bukan hanya diaplikasikan pada produk makanan, tetapi teknologi fermentasi sekarang ini merupakan salah satu teknologi dasar yang digunakan untuk menghasilkan obat-obatan maupun sumber daya energi yang terbarukan. Teknologi fermentasi merupakan teknologi yang erat kaitannya dengan potensi pemberdayaan alam, baik sebagai sumber makanan maupun sebagai sumber energi terbarukan.

\section{SOLUSI}

Melalui pengabdian masyarakat ini solusi yang kami tawarkan adalah;

a. Pengenalan dasar mengenai ilmu pengolahan pangan

b. Pengenalan dasar mengenai teknologi fermentasi, jenis-jenis fermentasi, mikroorganisme yang terlibat, perubahan fisiko kimia dan perubahan fungsionalitas dari produk makanan.

c. Pengenalan mengenai aneka produk fermentasi dipasar, nilai jual dan potensi pengembangan dimasa yang akan datang.

d. Praktek pembuatan minuman fermentasi

\section{METODE PELAKSANAAN}

Pelaksanaan pengabdian masyarakat akan dilakukan secara daring menggunakan platform zoom/teams kepada sekolah-sekolah SMA dibawah Yayasan. Siswa-siswa akan diberikan modul pelatihan yang sudah dipersiapkan sebelumnya, adanya kompetisi singkat dan pelatihan pembuatan produk fermentasi secara daring.

1. Pembinaan dalam bentuk penjelasan dan presentasi mengenai teknologi pangan dan teknologi fermentasi

- Jenis-jenis produk fermentasi dan teknologi fermentasi.

- Penerapan teknologi proses pengolahan yang dapat meningkatkan sifat fungsional dari produk fermentasi.

- Perubahan fisikokimia dari bahan baku selama proses fermentasi

- Aplikasi Teknik Sensori dalam menentukan kualitas mutu bahan makanan

- Sifat Sensori dari Minuman Fermentasi 
2. Diskusi terbuka serta tanya jawab mengenai aneka produk fermentasi dan potensinya.

- Siswa diajarkan metode pembuatan minuman fermentasi sederhana. Siswa diperkenalan pada bahan baku utama minuman fermentasi dan Teknik pengolahan untuk menghasilkan minuman fermentasi.

- Siswa membuat minuman fermentasi secara mandiri dan menyampaikan hasil karya pembuatan dalam bentuk presentasi

3. Evaluasi terhadap pelaksanaan pengabdian masyarakat yang mencakup:

- Kesesuaian kegiatan pelatihan dengan kebutuhan Sekolah Dian Harapan

- Ketercapaian tujuan kegiatan pelatihan dengan masalah yang dihadapi Sekolah Dian Harapan

- Kompetensi penyuluh.

- Keberlanjutan program PkM

4. Evaluasi secara berkala melalui komunikasi langsung dengan cara menjalin komunikasi via surat, email, telepon kepada Sekolah Dian Harapan

5. Desiminasi dan seminar hasil PkM

6. Kegiatan penyuluhan lanjutan direncanakan dalam bentuk summer program dan kegiatan perkenalan lanjutan pada bulan juli-Desember 2021 secara virtual melalui platform Zoom.

\section{HASIL DAN PEMBAHASAN}

Pertemuan via online dengan Bapak Alvin Wijaya, Head of Curriculum Coordinator di Sekolah Dian Harapan dilakukan selama tahun ajaran sebelumnya untuk memanfaatkan fasilitas daring yang sudah berkembang pesat dimasa pandemi, dengan tujuan untuk membagikan ilmu pengetahuan kepada lebih banyak siswa-siswa sekolah di pelosok Indonesia. Perkembangan Teknologi secara daring memungkinkan proses penyebaran informasi menjadi lebih mudah dan dapat mencakup bagian-bagian daerah yang selama ini sulit dijangkau. Pengenalan mengenai aneka jurusan ilmu alam dan teknologi dianggap dapat memberikan pengalaman yang baik bagi siswa-siswa menengah atas sebagai bahan pertimbangan untuk memutuskan tujuan kuliah di tahun selanjutnya. Melalui program ini siswasiswa diperkenalkan terhadap jurusan teknologi pangan secara umum, dan terhadap teknik fermentasi dan teknik penilaian makanan secara indera. Tim PKM kemudian melakukan konfirmasi ulang mengenai topik penyuluhan, jumlah peserta serta susunan acara pelatihan. Kemudian Tim PKM membuat materi penyuluhan dan juga menyiapkan materi karena dilangsungkan secara online dengan menggunakan zoom yang link nya sudah dibagikan kepada semua peserta webinar. Bahanbahan dan video tutorial pembuatan produk fermentasi dibagikan kepada peserta satu minggu sebelum hari webinar supaya dapat dipersiapkan terlebih dahulu. Selama satu minggu sebelum forum tanya jawab dibuka, untuk memudahkan proses komunikasi antara siswa SDH dengan tim PKM.

\section{PELAKSANAAN WEBINAR}

Tim PKM Jurusan Teknologi Pangan mempersiapkan seluruh perangkat untuk kegiatan webinar seperti: poster untuk sosialisasi kepada jemaat yang berisi informasi tanggal pelaksanaan, registrasi peserta, link zoom yang digunakan dan informasi Gratis, dan narasumber Jurusan Teknologi Pangan Universitas Pelita Harapan. Persiapan acara dimulai pukul 12.30 dengan Persiapan teknis peralatan webinar (sound, kamera, recording, sertifikat, publikasi, registrasi, kuesioner, host dan co-host), dan selanjutnya acara webinar dimulai pukul 13.00 hingga selesai.

Acara pembukaan dimulai pukul 13.00 diawali dengan Kata sambutan yang langsung disampaikan Ketua Program Studi Teknologi Pangan UPH oleh Bapak Ir. Wilbur Donald Pokatong, MSc., P.hD, dilanjutkan kata Sambutan dari pihak Sekolah Dian Harapan, Kepala Bidang Perencanaan Kurikulum, Bapak Alvin Wijaya. Spd, B.Ed. dan dilanjutkan dengan materi pokok webinar. Kegiatan webinar ini dihadiri oleh 93 orang peserta, yang terbagi menjadi siswa-siswa Sekolah Dian Harapan dan perwakilan guru Sekolah Dian Harapan. Peserta 
yang membuat produk secara mandiri sebesar 12 orang dari 5 Sekolah (SDH Manado, SDH Bogor, SDH Bangka, SDH Daan Mogot dan SDH Belitung). Beberapa hasil karya produk minuman fermentasi dari siswa-siswa SDH dapat dilihat pada bagian lampiran. Pada bagian pertama dari penyuluhan, diperkenalkan konsep terminologi, definisi, jenis produk Fermentasi, contoh-contoh hasil fermentasi khamir/ yeast dan perubahan fisikokimia pada produk pangan yang mengalami proses fermentasi. Selanjutnya peserta diajak untuk membuat produk minuman fermentasi bersama-sama dan dilatih untuk melakukan uji penilaian makanan dengan indera untuk mengamati hasil akhir produk fermentasi.

Fermentasi merupakan salah satu teknik pengolahan pangan yang memanfaatkan mikoorganisme simbiotik untuk memberikan nilai tambahan pada produk pangan [4].. Mikroorganisme simbiotik akan merubah komposisi fisika kimia dari bahan pangan, menguraikan komponen makro pada bahan makanan menjadi monomernya yang lebih mudah dicerna. Fermentasi juga menghasilkan senyawa-senyawa turunan yang memiliki sifat fungsional yang berperan dalam gizi dan Kesehatan manusia. Makanan yang difermentasi selain memiliki gizi yang baik, juga memiliki tekstur yang unik serta umumnya memiliki umur simpan yang lebih Panjang. Beberapa contoh makanan fermentasi yang umum ditemukan sehari-hari adalah roti, tape, brem, tempe, keju, yoghurt, sayur asin, kimchee dan lain lain. Makanan-makanan fermentasi ini memiliki cita rasa yang unik tergantung dari bahan baku yang digunakan serta mikroorganisme yang berperan didalam.

Mikroorganisme yang berperan dalam proses fermentasi makanan terbagi menjadi 3 golongan; bakteri (bakteri asam laktat yang homofermentative maupun heterofermentative seperti Lactobacillus sp, Bifidobacteria sp, Acetobacter sp.), Kapang (Rizhopus sp, Aspergillus sp, Pennicilium sp. dan lain-lain) dan Khamir (Saccharomyces sp, Hansenia Sp.). Mikroorganisme - mikroorganisme ini pada umumnya akan mengurai makromolekul seperti protein, karbohidrat dan asam lemak menjadi komponen yang lebih sederhana dan memproduksi asam-asam organik yang akan menurunkan keasaman makanan. Keasaman yang rendah akan menghambat pertumbuhan mikroorganisme yang bersifat pembusuk/patogenik, sehingga secara tidak langsung akan memperpanjang umur simpan dari bahan makanan tersebut.

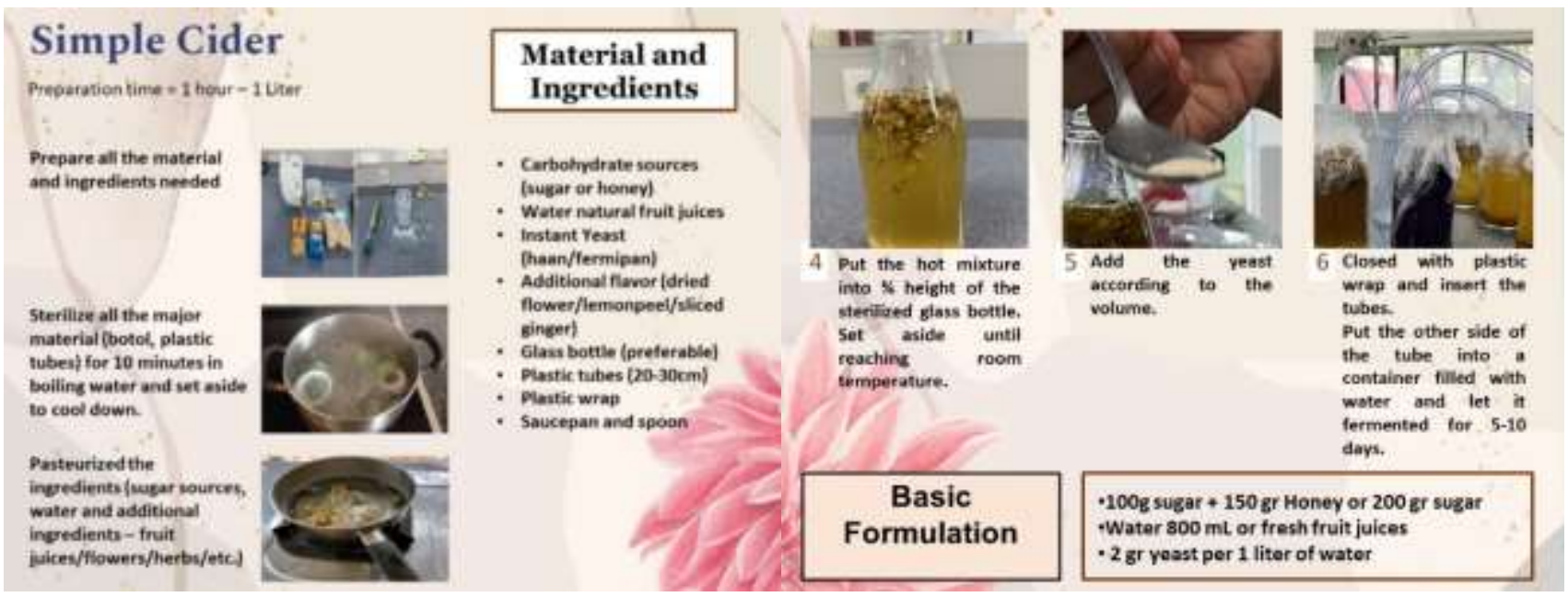

Gambar 1. Flyer Proses Pembuatan Minuman Fermentasi 


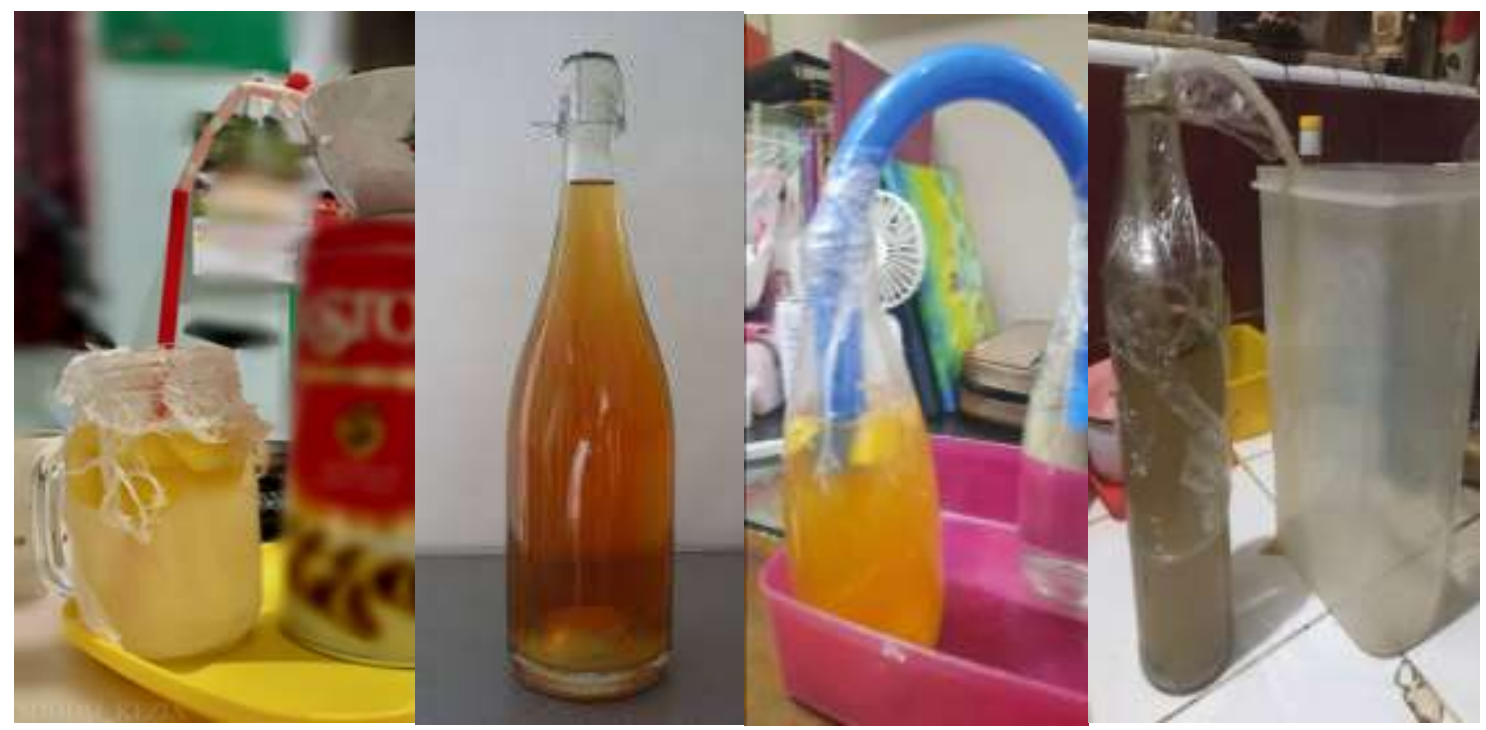

Gambar 2. Hasil pembuatan Cider siswa-siswa SDH (dari kiri-kanan; cider kulit lemon, cider apel, cider kulit lemon dan cider jahe).

Hasil penguraian makromolekul menjadi komponen yang lebih sederhana, akan meningkatkan kemampuan cerna produk pangan tersebut, sehingga memudahkan penyerapan gizi makanan. Beberapa bahan pangan yang memiliki dinding sel tebal ataupun zat antinutrisi, setelah proses fermentasi akan menjadi lebih ramah untuk dikonsumsi.

Senyawa mikronutrisi ini nanti juga akan berperan dalam menjaga kesehatan dan keragaman microflora saluran pencernaan manusia. Selama proses fermentasi, salah satu karakteristik yang berubah dari produk makanan adalah karakter rasa dan aroma. Fermentasi umumnya meningkatkan rasa manis, asam dan juga aroma-aroma khas dari bahan baku produk. Secara teoritis ada tiga aroma dasar yang terbentuk selama proses fermentasi [5]. Aromaaroma ini dapat diamati secara deskriptif maupun kuantitatif dengan menggunakan uji sensori. Aroma profile dari cider akan sangat bergantung dari bahan baku yang digunakan [5,7].

Uji sensori merupakan salah satu uji mutu yang penting dalam pengembangan produk makanan $[5,6]$. Uji sensori terbagi menjadi uji sensori yang bersifat deskriptif (penggambaran karakteristik) maupun uji sensori yang bersifat kuantitatif (pengukuran atau komparasi dengan standar). Panelis-panelis yang melakukan uji sensori juga terbagi menjadi panelis umum maupun panelis terlatih. Dengan melakukan uji sensori, karakter dari produk makanan dapat digambarkan maupun dibandingkan secara kuantitatif maupun kualitatif. Dalam pelatihan ini, siswa diajak untuk melakukan uji sensori secara sederhana dengan menggunakan lembar penilaian uji deskripsi, uji skoring dan uji hedonik pada produk makanan fermentasi yang diolah bersama.

Dari hasil uji sensori bersama beberapa produk fermentasi hasil karya siswa SDH, dapat dilihat bahwa dari skala 1-5, sebagian besar produk memiliki penerimaan rasa yang baik. lemon terbuat dari kulit jeruk lemon, yang memberikan aftertaste pahit yang jelas pada produk akhir fermentasi sehingga menyebabkan penerimaan produk secara sensori menjadi kurang baik. Cider jahe 2 dan cider apel memiliki penerimaan sensori yang sangat baik, sedangkan cider lemon terlihat memiliki penerimaan yang paling rendah (skala 3 dari 5). Hasil dari uji sensori dapat dilihat pada gambar.3

Karakter rasa dari minuman fermentasi ditentukan oleh bahan baku dari minuman 
fermentasi [7]. Kulit lemon memiliki aroma yang enak tetapi juga memiliki rasa pahit yang khas yang disebabkan oleh kandungan limonene didalam kulit jeruk lemon. Penampakan dari produk fermentasi cider juga masih cukup rendah, dikarenakan tidak adanya tahapan klarifikasi yang diterapkan dalam proses pembuatan cider. Minuman cider yang dibuat dari buah apel dan sari jahe memiliki skor penerimaan secara keseluruhan, rasa dan aroma yang baik.

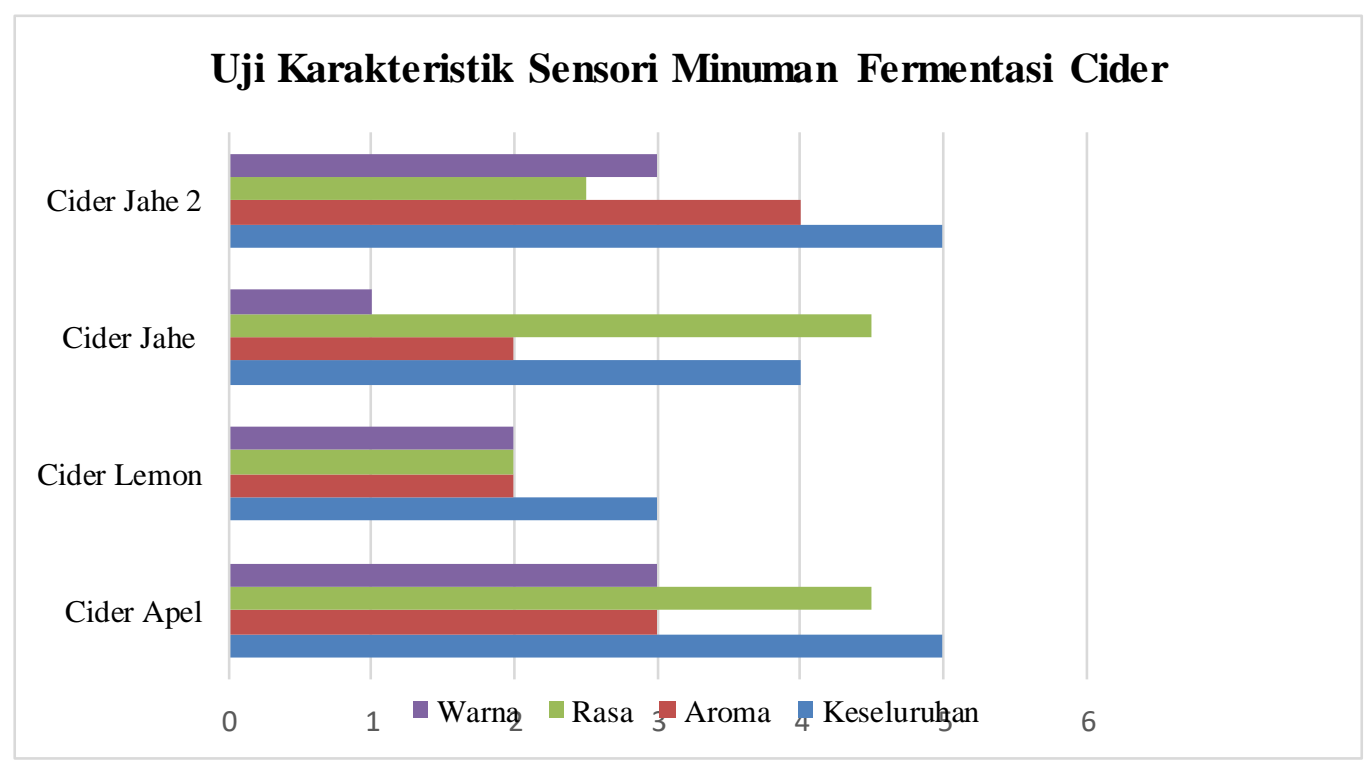

Gambar 3. Hasil Karya Produk Fermentasi Siswa-Siswa SDH

Setelah proses webinar selesai, siswa-siswa diminta untuk memberikan tanggapan terhadap proses pelatihan yang diberikan. Ada 41 responden dari peserta yang mengisi kuosiener, dimana $100 \%$ dari responden memberikan respon positif terhadap materi yang dibawakan. Ketertarikan terhadap topik terlihat pada sesi tanya jawab, dimana siswa-siswa memberikan pertanyaan-pertanyaan yang menarik dan dalam seputar topik fermentasi. Beberapa pertanyaan dari sesi Q \& A yang diadakan adalah:

1. Fungsi dari penggunaan selang+air pada proses fermentasi

2. Fungsi dari uji Hedonik dalam pengembangan produk pangan

3. Tahapan-tahapan perubahan fisikokimia dari yeast

4. Tingkat keamanan pangan dari produk fermentasi

5. jenis-jenis uji sensori yang umum dilakukan pada produk pangan.
Tabel 1. Topik-topik lanjutan yang diminati peserta

\begin{tabular}{|c|c|}
\hline Topik & Persen \\
\hline $\begin{array}{l}\text { Bidang-bidang pekerjaan yang } \\
\text { berkaitan dengan Teknologi Pangan }\end{array}$ & $47 \%$ \\
\hline $\begin{array}{l}\text { Pengembangan Produk / Diversifikasi } \\
\text { Pangan }\end{array}$ & $3 \%$ \\
\hline $\begin{array}{l}\text { Teknologi Pengolahan Pangan } \\
\text { (Teknologi susu/permen/roti/buah- } \\
\text { sayur/fermentasi etc) }\end{array}$ & $47 \%$ \\
\hline $\begin{array}{lcr}\begin{array}{l}\text { Peraturan } \\
\text { pangan }\end{array} & \begin{array}{l}\text { Legal dan } \\
\text { (Standarisasi }\end{array} & \begin{array}{r}\text { Keamanan } \\
\text { nasional } \\
\text { indonesia } \\
\text { internasional) }\end{array} \\
\end{array}$ & $3 \%$ \\
\hline
\end{tabular}

Selain itu lebih dari $85 \%$ responden sudah membuat atau tertarik untuk membuat produk fermentasi dirumah. Beberapa topik lanjutan dan ketertarikan untuk mengikuti training lanjutan ditujukan dari terutama berkaitan dengan bidang pekerjaan dan juga teknologi pengolahan pangan 
dapat dilihat dari hasil kuosiener berikut ini:

Apakah anda mendapatkan informasi baru setelah mengikuti workshop ini? 41 responses
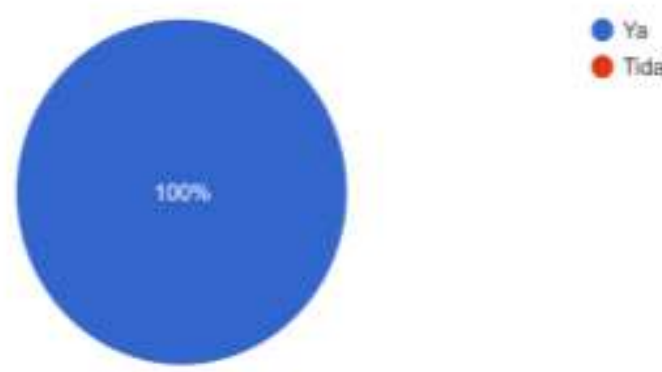

C Tidak

Apakah presentasi yang dibawakan menarik minat kalian? Apakah presentasi yang dibawakan mudah dimengerti?
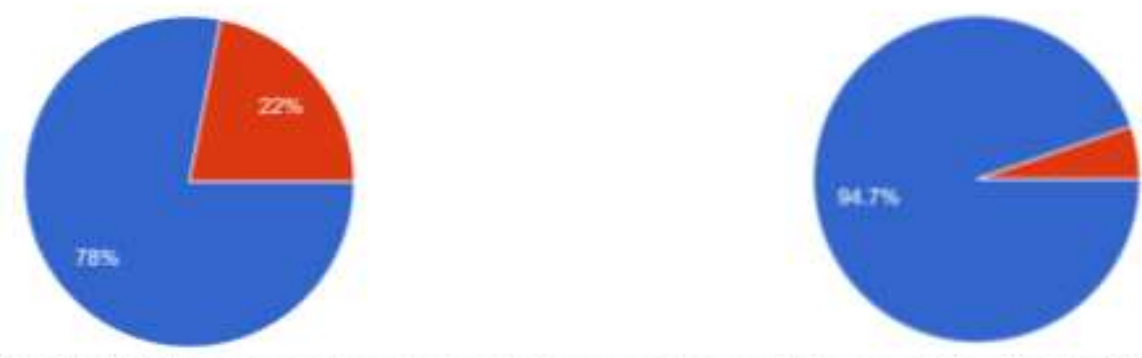

Apakah kalian mencoba atau tertarik mencoba produk yang diperlihatkan? 41 responses

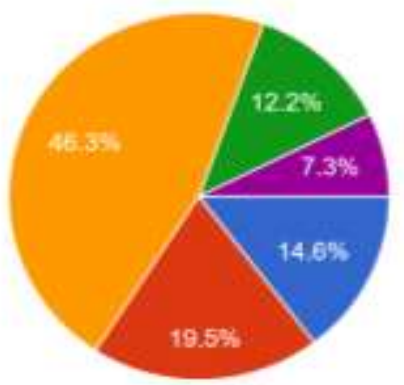

- Ya sudah mencoba

- Ya akan mencoba

C Mungkin mau menooba

P Tidak tertarik

C Ya

Gambar 4. Hasil Kuosiener Pengabdian Masyarakat 


\section{SIMPULAN DAN SARAN}

\section{KESIMPULAN}

Kegiatan $\mathrm{PkM}$ pelatihan secara daring mengenai produk minuman fermentasi, manfaat dan potensinya dalam kehidupan di sekolah dian harapan telah dilaksanakan dengan baik.. Kegiatan ini berlangsung dengan baik berkat kerjasama dari Fakultas Sains dan Teknologi, Pihak Head Office Sekolah Dian Harapan dan Tim PKM yang terdiri dari dosen, dan mahasiswa Jurusan Teknologi Pangan UPH. Kegiatan webinar ini dihadiri oleh 93 orang peserta dari 11 Sekolah Dian Harapan di Seluruh Indonesia; SDH Lippo Village, Tangerang, SDH Lippo Cikarang, SDH Makassar, SDH Daan Mogot, SDH Ranotana, Sekolah Palembang Harapan, SDH Holland Village, SDH Kupang, SDH Bangka (2016), SDH Lubuklinggau, SDH Medan dan SDH Bogor. Siswa-siswa yang berpartisipasi dalam pembuatan produk fermentasi mendapatkan hadiah berupa Jaket UPH dan sekolah-sekolah yang berpartisipasi mendapatkan sumbangan berupa buku-buku yang terkait dengan produk fermentasi dan teknologi fermentasi tepat guna.

\section{SARAN}

Kegiatan PKM berupa pelatihan ini dapat terus dilakukan oleh Jurusan Teknologi Pangan UPH dengan topik-topik lain yang berhubungan aplikasi teknologi pengolahan pangan pada aneka produk lokal, terutama yang memiliki sifat fungsional, atau yang mampu memberikan alternatif makanan sehat bergizi bagi masyarakat luas. Penggunaan bahan lokal dan bahan alami dalam pembuatan aneka produk inovatif dapat meningkatkan ketertarikan siswa dalam bidang ilmu pengetahuan dan teknologi secara umum dan bidang Pengolahan Pangan secara khusus.

\section{KEBERLANJUTAN}

Kegiatan PKM ini dilanjutkan dengan kegiatan UPH-SDH summer program yang diadakan pada tanggal 28 juni - 2 juli 2021, yang befokus pada ketahanan pangan, pengenalan akan nutrisi dan kualitas bahan pangan yang baik.

\section{UCAPAN TERIMAKASIH}

Ucapan terimakasih disampaikan kepada Sekolah Dian Harapan dan LPPM UPH atas dukungan dana yang diberikan dalam pelaksanaan kegiatan PKM ini.

\section{DAFTAR PUSTAKA}

[1] E. Smith, "Is there a crisis in school science education in the UK?," Educational Review, vol. 62, no. 2, pp. 189-202, 2010.

[2] S. Shirazi, "Student experience of school science," International Journal of Science Education, vol. 39, no. 14, pp. 1891-1912, 2017.

[3] F. Astri, "PGSD Binus," Bina Nusantara , 29 juni 2016. [Online]. Available: https://pgsd.binus.ac.id/2016/06/29/memunculkan -daya-tarik-pelajaran-sains/. [Accessed $11 \quad 12$ 2020].

[4] Vivi Nurhadianty, in Pengantar Teknologi Fermentasi di Industri, Malang, Universitas brawijaya, 2018, p. 140.

[5] Calugar, P.C., Coldea, T.E., Salant, `a, L.C., Pop, C.R., Pasqualone, A., Burja-Udrea, C., Zhao, H., Mudura, E., An Overview of the Factors Influencing Apple Cider Sensory and Microbial Quality from Raw Materials to Emerging Processing Technologies. Processes. 2021, vol 9 no. 502.

[6] Swiader, K., Marczewska,M. Trends of Using Sensory Evaluation in New Product Development in the Food Industry in Countries That Belong to the EIT Regional Innovation Scheme. Foods. 2021, Vol 10, no. 446. pp1-25.

[7] Los, Paulo R., Braga, Cintia M., Carvalho, Jose R., Nogueira, Alessandro. Application of Sensory Analyses In The Development Of A New Apple Cider. 2017. Revista Brasileira de Tecnologia Agroindustrial vol 11, no 1, pp 21502168. 